\title{
HEALTH EFFECTS OF OCCUPATIONAL EXPOSURE TO CRYSTALLINE SILICA IN THE LIGHT OF CURRENT RESEARCH RESULTS
}

\author{
ZDROWOTNE SKUTKI NARAŻENIA ZAWODOWEGO NA KRYSTALICZNĄ KRZEMIONKĘ \\ W ŚWIETLE WYNIKÓW AKTUALNYCH BADAŃ
}

Nofer Institute of Occupational Medicine / Instytut Medycyny Pracy im. prof. J. Nofera, Łódź, Poland Department of Environmental Health Hazards / Zakład Środowiskowych Zagrożeń Zdrowia

\begin{abstract}
Crystalline silica is commonly found in the work environment. Possible health effects of occupational exposure continue to be the subject of extensive research. The aim of this paper was to analyze the recent findings concerning the health effects of exposure to crystalline silica, taking into account different levels of exposure. This work is based on the relevant information from the papers retrieved from the following databases: EBSCO, Scopus, ScienceDirect, and Web of Science, using the following keywords: crystalline silica, quartz, health effects. The review of the results confirms the multi-faceted harmful effects of crystalline silica. Prolonged occupational exposure, apart from silicosis and non-cancer respiratory diseases, may also result in the development of lung cancer, and autoimmune and chronic kidney diseases, the pathogenesis, which has not been completely explained yet. The exposure to the crystalline silica at concentrations close to the current occupational exposure limit value does not exclude the risk of the following pathologies: silicosis, lung cancer, other lung diseases and renal diseases. It is not feasible to completely eliminate the crystalline silica dust from the work environment. The best way to reduce the health effects of the exposure is to minimize the concentrations of silica dust. Further progress in clarifying the true mechanisms of interaction between silica dust and lung cells, the determination of the importance of surface properties of the silica particles in the pathogenic processes and explaining the effects of co-morbid dust in the work environment may help to prevent the harmful effects of silica dust. Med Pr 2014;65(6):799-818
\end{abstract}

Key words: crystalline silica, quartz, silicosis, health effects, lung cancer, occupational exposure

\begin{abstract}
STRESZCZENIE
Krystaliczna krzemionka powszechnie występuje w środowisku pracy. Możliwe zdrowotne skutki zawodowego narażenia są nadal przedmiotem wielu badań. Celem niniejszej pracy była analiza aktualnych wyników badań dotyczących zdrowotnych skutków narażenia na krystaliczną krzemionkę, z uwzględnieniem różnych poziomów ekspozycji. Podstawę opracowania stanowiły publikacje zawarte w bazach: EBSCO, Scopus, ScienceDirect oraz Web of Science, znalezione z użyciem słów kluczowych: crystalline silica, quartz, health effects. Przegląd wyników badań potwierdza wielokierunkowe szkodliwe działanie krystalicznej krzemionki. W następstwie długotrwałej zawodowej ekspozycji, oprócz krzemicy płuc i nienowotworowych chorób układu oddechowego, może rozwijać się rak płuca, a także choroby o niewyjaśnionej ostatecznie patogenezie - choroby autoimmunizacyjne i choroby nerek. Ekspozycja na krystaliczną krzemionkę występującą w zakresie stężeń zbliżonych do obecnie obowiązujących wartości dopuszczalnych nie wyklucza ryzyka wystąpienia następujących patologii: krzemicy, raka płuca, innych chorób płuc oraz chorób nerek. Wyeliminowanie pyłu krystalicznej krzemionki ze środowiska pracy jest praktycznie niemożliwe, a głównym sposobem ograniczania zdrowotnych skutków narażenia nadal pozostaje jego minimalizowanie. Ważnym elementem zapobiegania szkodliwemu działaniu krzemionki może być dalszy postęp w dokładnym wyjaśnieniu mechanizmów interakcji pyłu krzemionkowego z komórkami, ustalenie znaczenia właściwości powierzchniowych cząstek w patogenezie oraz dokładne poznanie interakcji z pyłami współwystępującymi w środowisku pracy. Med. Pr. 2014;65(6):799-818
\end{abstract}

Słowa kluczowe: krystaliczna krzemionka, kwarc, krzemica, skutki zdrowotne, rak płuca, narażenie zawodowe

Corresponding author / Autorka do korespondencji: Aleksandra Maciejewska,

Nofer Institute of Occupational Medicine, Department of Environmental Health Hazards,

św. Teresy 8, 91-348 Łódź, Poland, e-mail: altema@imp.lodz.pl

Received: 2014, March 7, accepted: 2014, April 23

\section{INTRODUCTION}

Silicon dioxide $\left(\mathrm{SiO}_{2}\right)$ commonly known as silica, is one of the most ubiquitous chemical compounds in the world. Quartz, one of the crystalline forms of silica, represents a very frequent component of the natural environment. It represents $12 \%$ of the Earth's crust, occurs in almost all types of rocks and is an important raw material. Cristobalite is an another form of crystalline silica, which rarely occurs in nature, but in the industrial conditions, it may be formed as a result of thermal transformations of other forms of crystalline silica, kaolinite, clay minerals or amorphous silica, if they are subjected to the temperature higher than $800^{\circ} \mathrm{C}(1,2)$. 
Siliceous materials are extensively used in construction, for the production of glass, ceramics, foundry molds and cores, metallic silicon, silicium iron, sodium silicate, organosilicon compounds, refractory products, friction and filter materials and fillings. Quartz crystals are used in optical and electrical instruments (2).

Crystalline silica is one of the most common factors harmful to health in the work environment, particularly in mining and extractive industries, fuel and energy production, metallurgical plants, ceramic products industry, house-building and construction industries, refractory industry, as well as in the chemical industry, glass manufacture, agriculture and horticulture (1). Adverse effects of crystalline silica in humans are associated with the accumulation of respirable dust in the alveoli and health effects of the exposure include: silicosis and its complications connected with bacterial or fungal infections, other non-cancer respiratory diseases (e.g., chronic obstructive pulmonary disease), lung cancer, cancers located outside the respiratory system, autoimmune and chronic kidney diseases (3). Although the adverse effects of crystalline silica have been known for a long time, the research aiming at explaining the determinants of the known pathologies as well as at detecting the yet unknown long-term effects of exposure to this factor still continues.

The aim of this study was to analyze the current findings concerning the health effects of exposure to crystalline silica in the workplace, taking into account the different levels of exposure.

\section{MATERIAL AND METHODS}

The present work uses English-language publications collected in the following databases: EBSCO, Scopus, ScienceDirect, and Web of Science, and found using the keywords: crystalline silica, quartz, health effects, silicosis, lung cancer. In the case of lung cancer as an effect of exposure to crystalline silica, selection of literature was limited mainly to the works containing the results of meta-analyzes and pooled analyzes. The bulk of the accumulated literature was published over the years 2000-2012; but some publications important for the studied problems were published in the years 1985-1999. Recent publications by the International Agency for Research on Cancer (IARC), the American Conference of Governmental Industrial Hygienists (ACGIH) and the National Institute for Occupational Safety and Health (NIOSH) have been also included in the analysis.

\section{RESULTS}

\section{Silicosis}

Silicosis is a result of deposition of silica dust particles with a diameter less than $10 \mu \mathrm{m}$ in the alveoli and terminal bronchioles. There are 3 types of silicosis, namely: acute silicosis, accelerated silicosis and chronic silicosis.

Acute silicosis (silicoproteinosis, silicolipoproteinosis) develops as a result of exposure to very high (probably up to $100 \mathrm{mg} / \mathrm{m}^{3}$ ) concentrations of crystalline silica within a period ranging from a few weeks to 4 years. The resultant pathological changes are characterized by hypertrophy and hyperplasia of type II pneumocytes, which under the influence of dust produce excessive amounts of proteins and surfactant, leading to silica-induced lipoproteinosis. The progression of the disease is very rapid, resulting in a considerable impairment of gas exchange in the lungs. The radiographic image usually does not show the changes typical of other forms of silicosis (3-5).

Accelerated silicosis is a result of exposure to crystalline silica at concentrations of several tens $\mathrm{mg} / \mathrm{m}^{3}$ over a period of several years. It develops after 4-10 years and is characterized by a clinical image similar to chronic silicosis, but with a higher pathological progression, while the fibrotic changes in the lung may be more irregular and more dispersed $(3,4,6)$. At present, this form of silicosis is mainly encountered in developing countries, among the miners employed in small mines, and its risk is estimated to amount to $30-50 \%$ after about $3-5$ years of exposure (6).

Chronic silicosis is the most common form of silicosis. The disease develops after at least 10 years of exposure to relatively low levels of crystalline silica. It is understood that the deposition in the lung of 1-3 g respirable crystalline silica is sufficient to initiate the development of this form of pneumoconiosis $(5,7)$, and the morbid process may progress even after cessation of the exposure $(1,8)$. The pathogenesis of silicosis has not been yet completely elucidated. The major contributor is the direct impact of particulate matter on the macrophages and other cells of the alveoli. The development of pathological changes is a series of successive inflammatory processes, immune and fibrotic reactions leading to the formation of nodular (focal) or diffused pulmonary fibrosis (3-5). The diagnosis of silicosis is based primarily on radiological examination, and observed changes are classified according to the criteria set by the International Labour Organisation - ILO 2002 (9). 
The research on the incidence of silicosis in the people exposed to crystalline silica has continued for several decades and the results have been published in several review papers $(3,10-12)$. Table 1 shows the results of epidemiological studies on the risk of silicosis published during the recent 25 years, involving large exposed groups.

Studies by Park et al., Steenland et al., and Rosenman et al. have shown that the higher-than-acceptable risk of developing silicosis, assumed to be $1 \times 10^{-5}-1 \times 10^{-3}$, is associated with virtually every exposure to respirable crystalline silica (22-24). The value of the risk associated with a 45 -year exposure, assuming 85 -year lifetime, is $0.2-0.5 \%$ in the case of exposure to very low levels - about $0.01 \mathrm{mg} / \mathrm{m}^{3}$ (the dose: $0.45 \mathrm{mg} / \mathrm{m}^{3} \times$ years) and $2-3 \%$ in the case of exposure to concentrations close to $0.02 \mathrm{mg} / \mathrm{m}^{3}$ (the dose: $0.9 \mathrm{mg} / \mathrm{m}^{3} \times$ years) (22).

The risk associated with cumulative exposure to about $1-2 \mathrm{mg} / \mathrm{m}^{3} \times$ years is estimated to range from $1 \%$ to $20 \%$ (median: $5 \%)(16,19,22,23,26)$. In the case of higher doses, from 4 to $6 \mathrm{mg} / \mathrm{m}^{3} \times$ years, corresponding to 40 years of exposure to crystalline silica concentration equal to $0.1-0.15 \mathrm{mg} / \mathrm{m}^{3}$, the risk of silicosis ranges from several per cent to several ten percent $(15,16,26)$. The highest cumulative exposure of over $6 \mathrm{mg} / \mathrm{m}^{3} \times$ years involves the risk of $8-77 \%$ (the average around $40 \%$ ) $(17-19,23)$. The differences in the level of the risk of silicosis estimated in various studies may be caused by several factors:

The adopted criterion for diagnosing the silicosisrelated changes in the radiographic image of the lungs (shading category $1 / 0,1 / 1,2 / 1$ or $\geq 2 / 1$ according to the ILO 2002 (9)) $(15,16,18,22-24)$.

Erroneous estimation of exposure in the people with silicosis, especially in the cases of people exposed decades earlier (27).

Different time of observation of the exposed people; silicosis is often diagnosed after more than 30 years of latency and many years after retirement $(8,18,28)$.

The results of the studies on mortality due to silicosis (Table 2) are more coherent than the results of the studies on the incidence of the disease, although silicosis is rarely the direct cause of death (27). Hedlund et al. and Mannetje et al. have found that the risk of death from exposure to respirable crystalline silica at doses below $2 \mathrm{mg} / \mathrm{m}^{3} \times$ years is close to $1 \%$, while it has been found to be slightly higher if the dose exceeded $2 \mathrm{mg} / \mathrm{m}^{3}$ xyears $(27,28)$. The standardized mortality ratios (SMRs) due to silicosis resulting from intense exposure may reach very high values ranging 


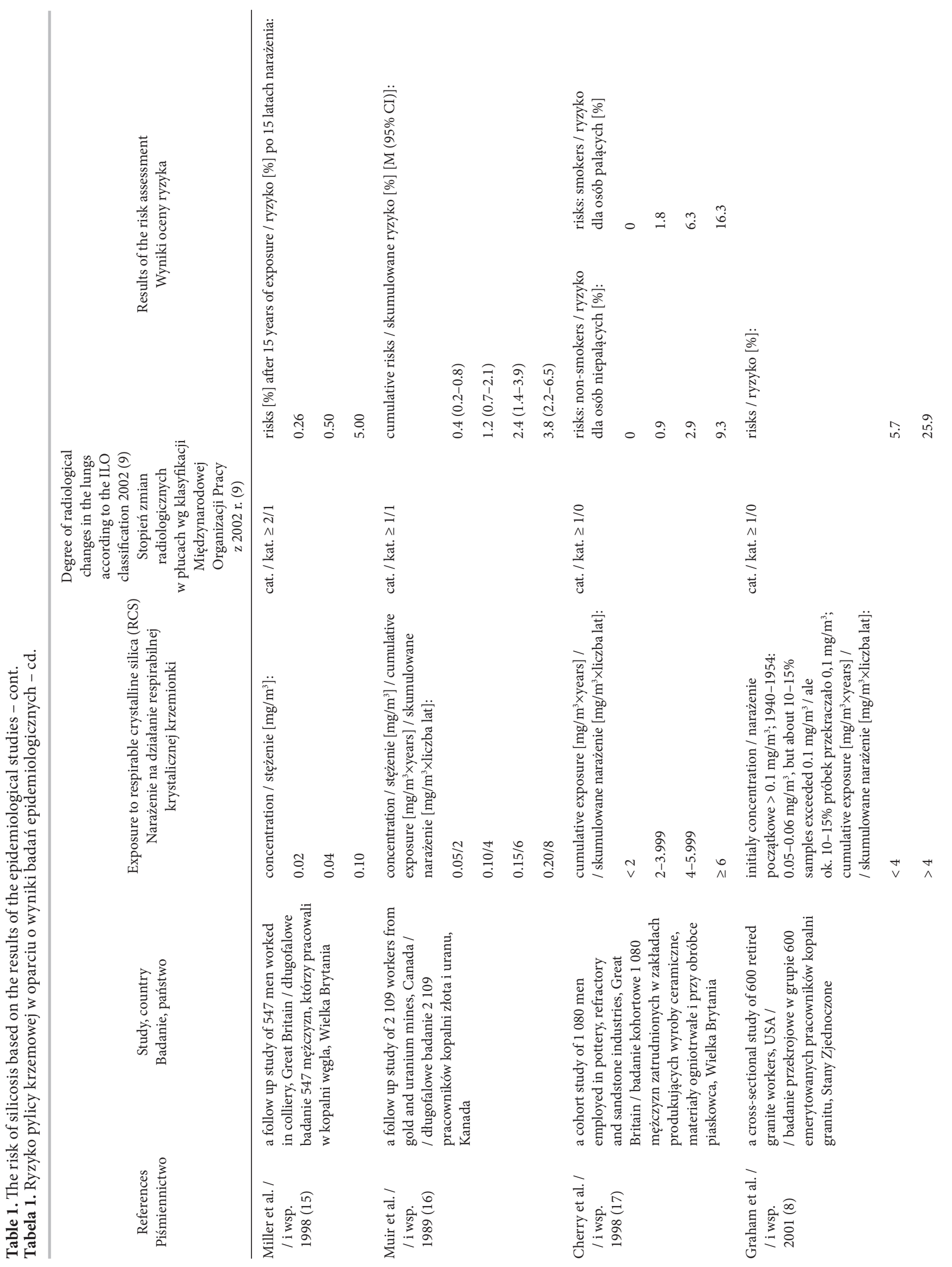




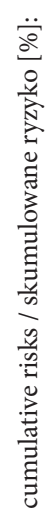
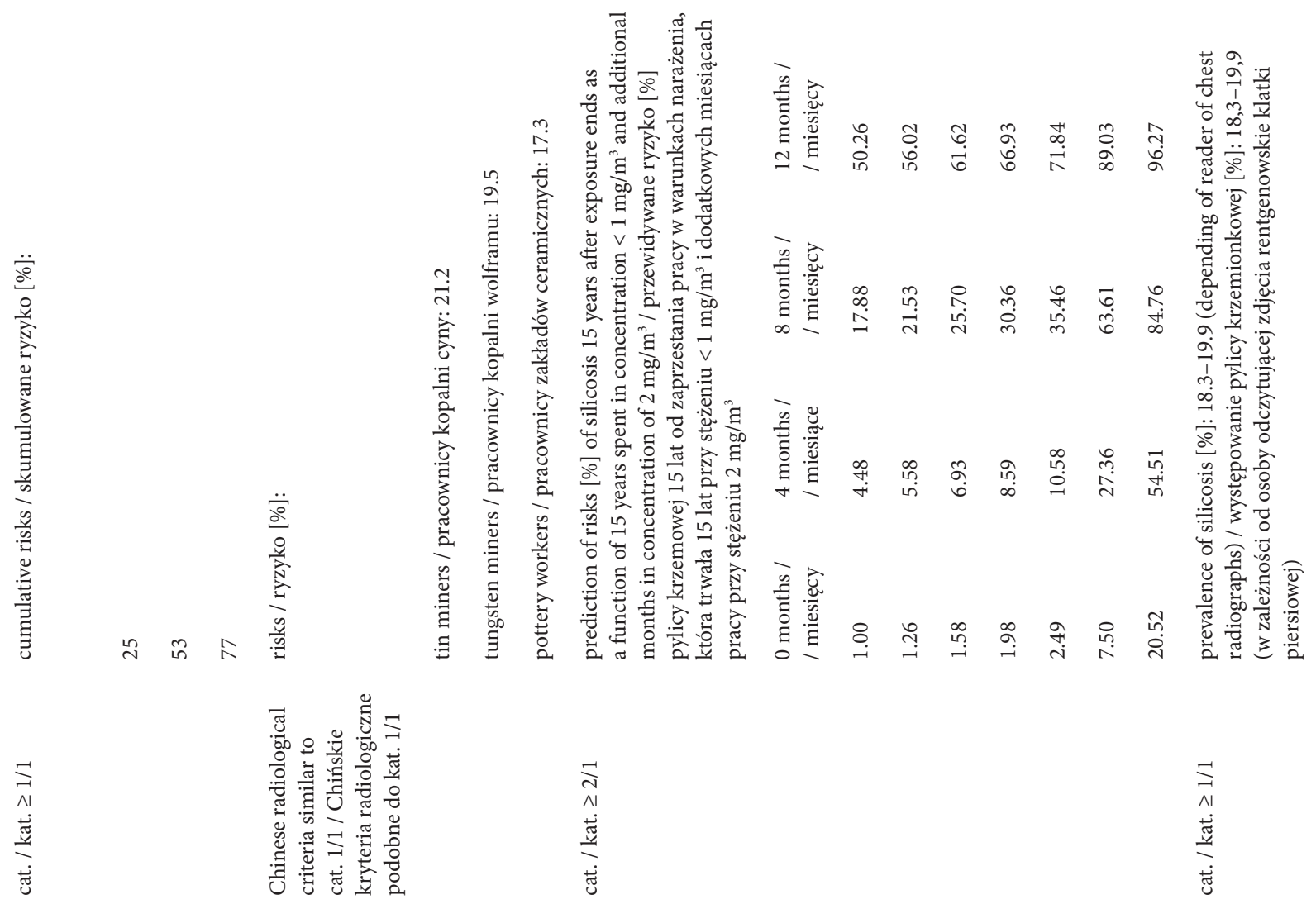

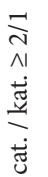

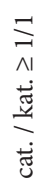
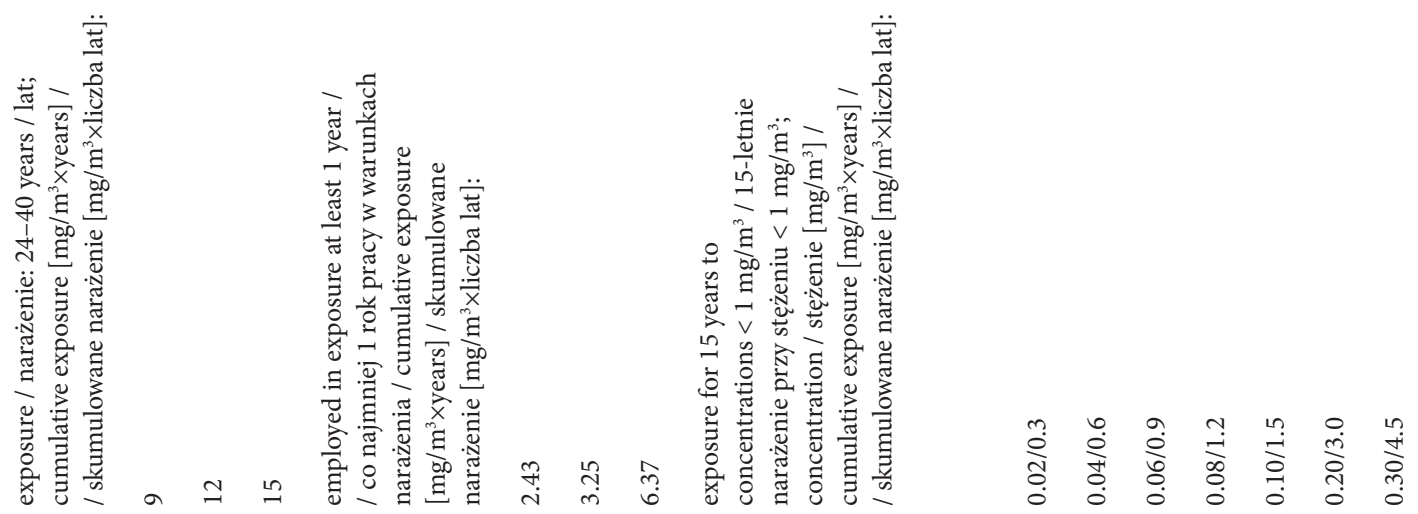

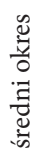

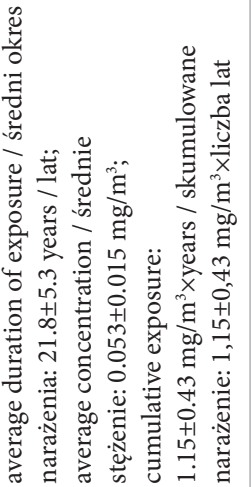

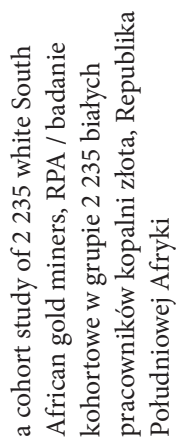
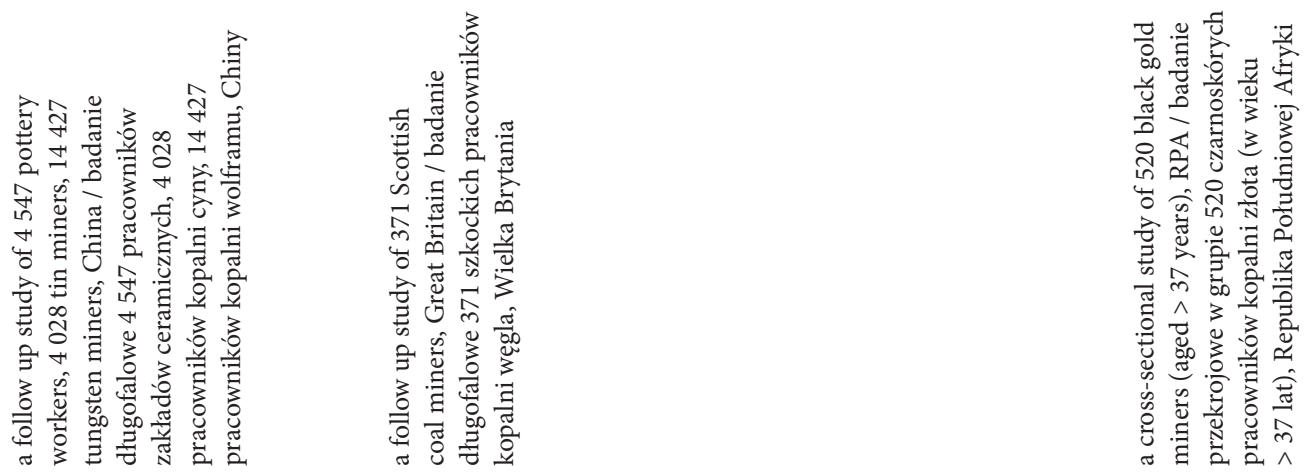

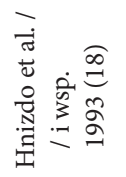

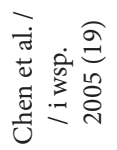

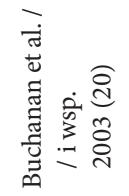

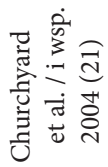




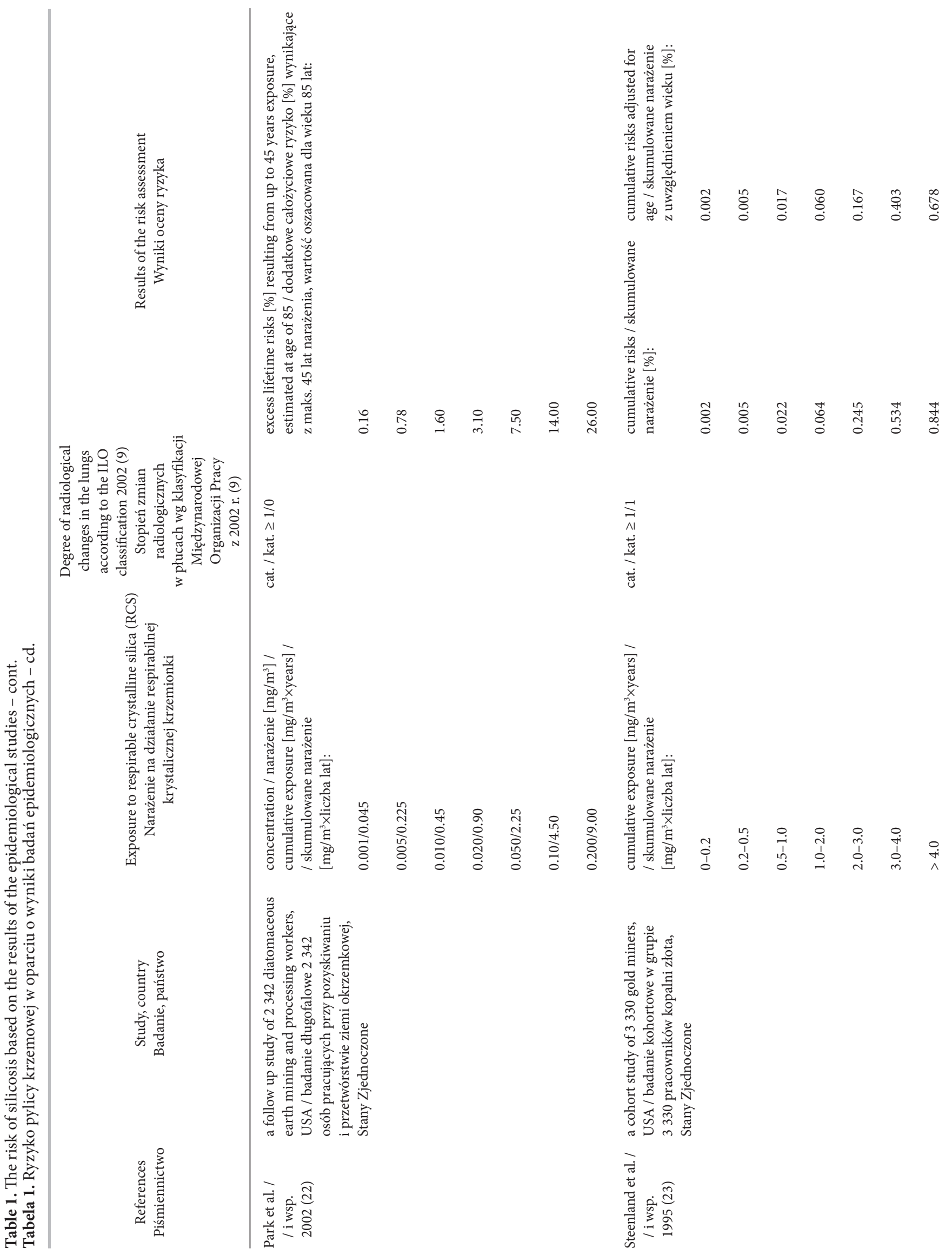




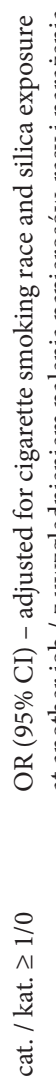

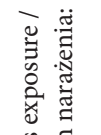

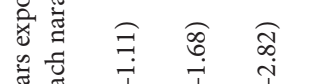

竞离

离衣

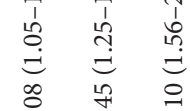

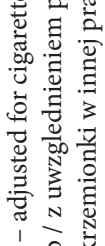

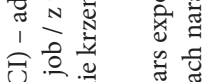

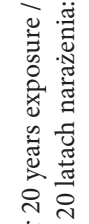

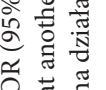

तับ

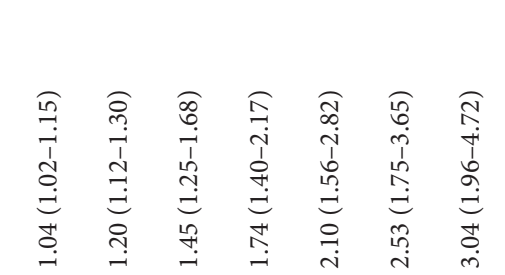

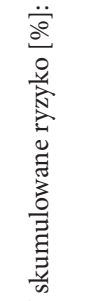

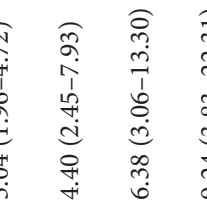

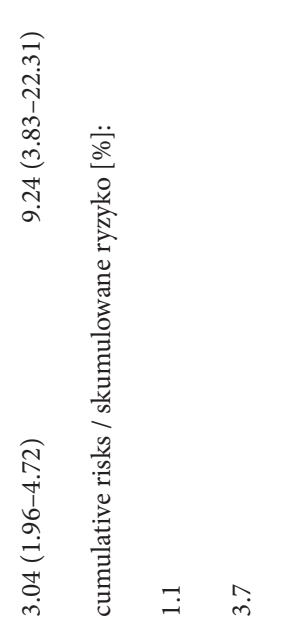

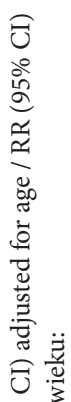

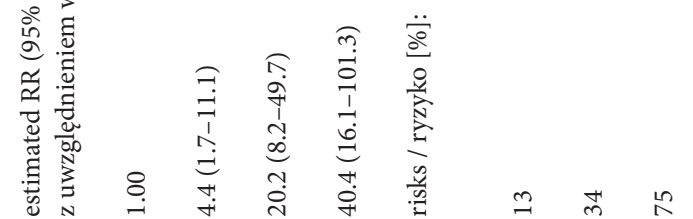

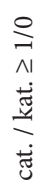

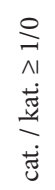

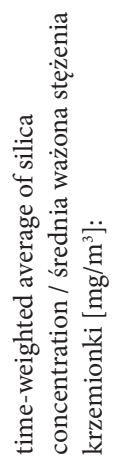
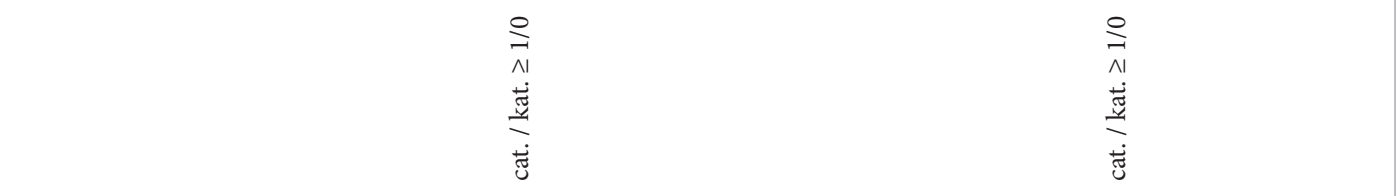

要

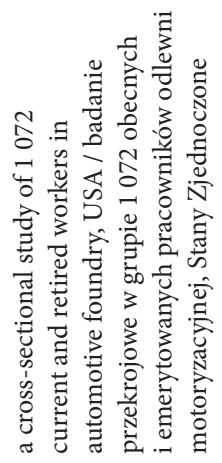

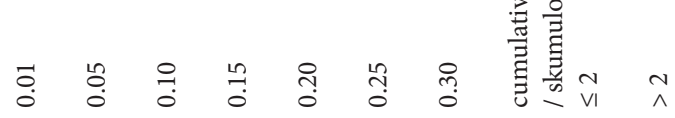
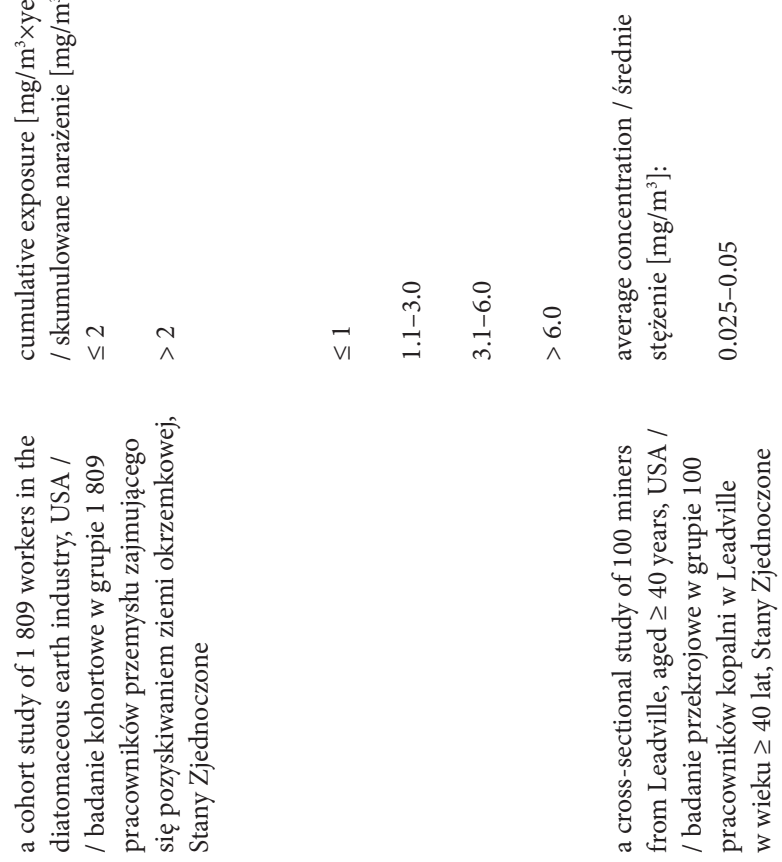

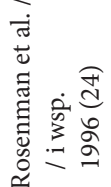

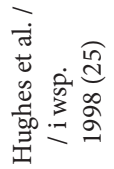

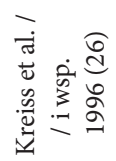


from 20 to over 500 (29-32). In a study conducted by Marinaccio et al. it has been also found that the level of that ratio depended on gender; it was significantly higher in women than in men (31).

The abovementioned data indicate that the most important factor in the occurrence of silicosis is the cumulative exposure to respirable crystalline silica and the time of the 1st exposure $(18,23,25,26,28)$. Hnizdo et al. have indicated that the relationship between the risk of silicosis and the dose up to $4 \mathrm{mg} / \mathrm{m}^{3} \times$ years is linear; at higher doses, the risk of silicosis increases in a manner similar to an exponential function (18). Multiple increase in the risk was also noted for the doses exceeding $2 \mathrm{mg} / \mathrm{m}^{3} \times$ years followed by additional several months of exposure to crystalline silica at concentrations higher than $2 \mathrm{mg} / \mathrm{m}^{3}$ (20). Yet another factor increasing the risk of developing silicosis consists in the exposure to freshly fractured silica dusts produced during crushing, grinding or pulping siliceous materials $(3,33)$. The modification of the surface properties of such particles by coal mine dusts or clay dusts, i.e., minerals, which cause occlusion of the silica particles, as well as aluminum salts and metallic iron, can lead to reduction of biological activity of crystalline silica (34). It is believed that the weaker fibrotic effect of such dusts results in reducing the risk of silicosis among the workers employed in factories manufacturing ceramic products $(14,19)$ and in coal mines $(15)$.

The relationship between silicosis and tobacco smoking has not been fully resolved. The results suggesting additive effect of both factors may be biased by an error resulting from an incorrect interpretation of non-specific radiographic changes in the lungs of smokers (35).

\section{Systemic silicosis (extrapulmonary silicosis)}

Silicotic patients happen to develop silicotic-like nodules in organs other than lungs. It is believed that these changes occur as a result of the transportation of the respirable dust with blood and/or lymph beyond the respiratory system, mainly to the liver, spleen, pancreas or bone marrow. Other factors, such as immune responses, are also suspected of being involved in the development of those changes $(36,37)$.

\section{Complications of silicosis}

Silicosis may be complicated by severe bacterial or fungal infections, developing as a result of the impairment of macrophage phagocytic function by the crystalline silica dust. In the relevant literature, silicotuberculosis

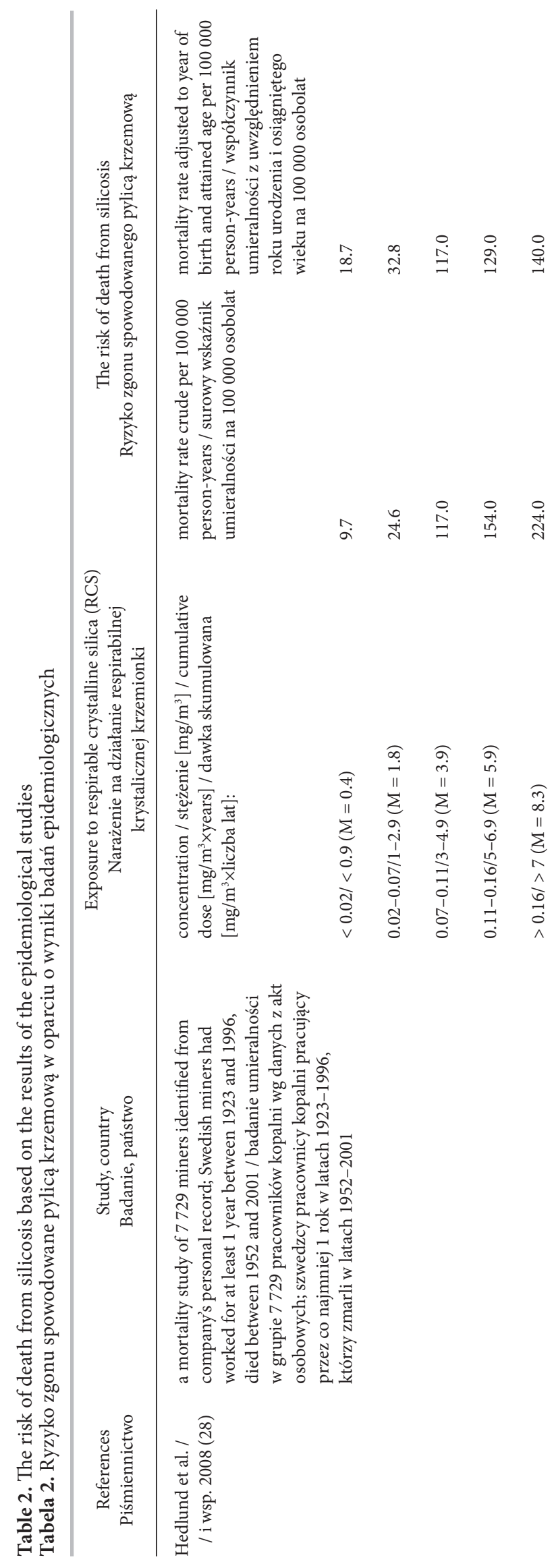




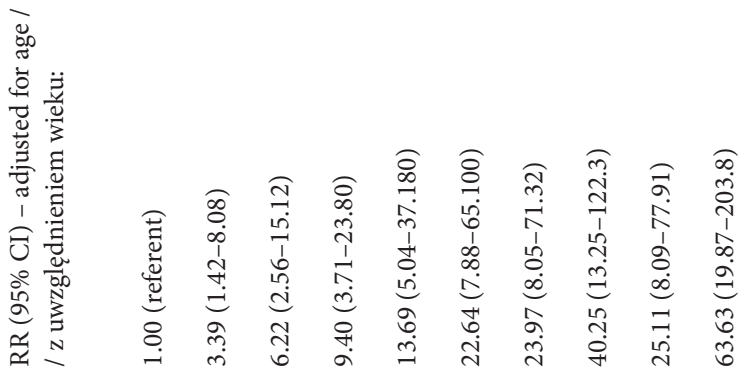

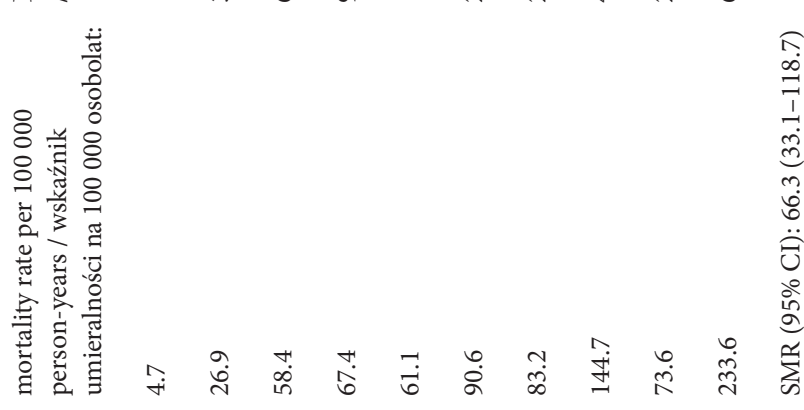

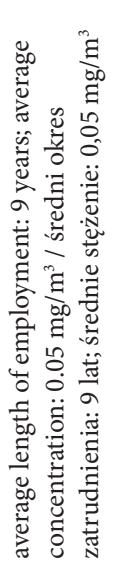

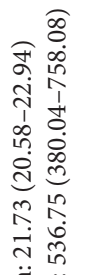

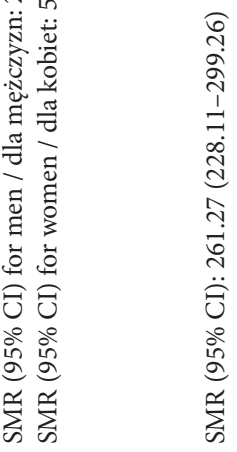

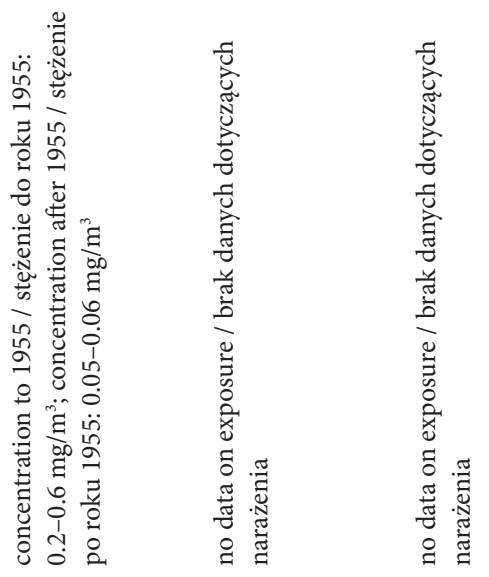

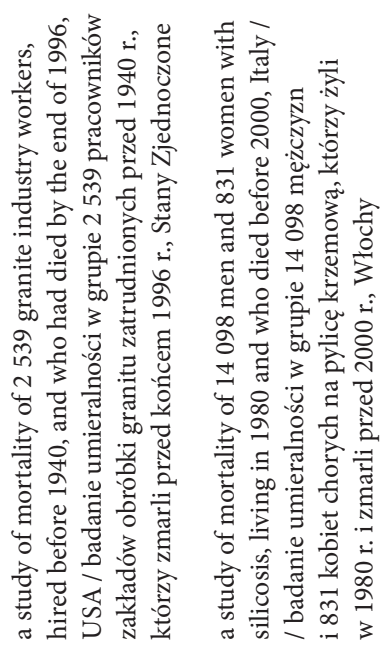

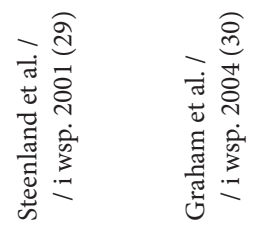

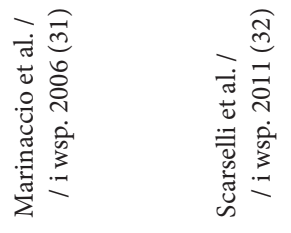

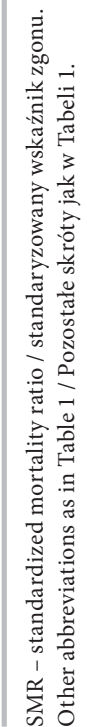


is the most frequently reported complication, while mycobacteriosis, nocardiasis, cryptococcosis (torulosis) are considerably less frequent (3). The analysis of the death certificates of the silicotic patients living in Tuscany and Lazio, Italy, showed a significant increase in mortality due to infectious diseases to the $\mathrm{SMR}=3.11$ (95\% CI: 1.38-7.01) (31,32). In a study of mortality due to tuberculosis in the silicotic workers, the SMR values ranging from 2.89 (95\% CI: $2.20-3.80$ ) to 10.47 (95\% CI: 4.24-25.85) $(31,32,38)$ were observed, and the mortality odds ratio (OR) for silicotuberculosis as compared to a non-silicotic control group amounted to 39.5 (95\% CI: 16.9-92.4) (39). The human immunodeficiency virus (HIV) infection in the patients with pulmonary silicosis additionally increases the risk of developing tuberculosis (40). The odds of developing silicotuberculosis increase in proportion to the time of exposure (38) and the dose of respirable crystalline silica (30).

Other frequent non-infection-related complications of silicosis include enlargement of the right ventricle of the heart (cor pulmonale) and the progressive right ventricular circulatory failure (3).

\section{Other non-malignant respiratory diseases}

The workers exposed to crystalline silica suffer also from the following diseases: chronic obstructive pulmonary disease (COPD), chronic bronchitis and emphysema (3). Studies on the relationship between exposure to silica and the occurrence of the COPD and chronic bronchitis are difficult to conduct and evaluate, as tobacco smoking is the major cause of these diseases. An additional factor complicating the study of this relationship is the fact that the particle size fraction responsible for the development of diseases located in the bronchial tree, and in the thoracic fraction, is different from that involved in the development of silicosis and pulmonary cancer.

Park et al. (22) who studied the workers mining and processing diatomite has estimated that the risk of developing lung diseases other than cancer, pneumoconiosis and pulmonary inflammation increases in proportion to the dose of dust, and ranges from $0.11 \%$ at a dose of $0.045 \mathrm{mg} / \mathrm{m}^{3} \times$ years to $19 \%$ at a dose of $9-10 \mathrm{mg} / \mathrm{m}^{3} \times$ years. The risk of death from these diseases, estimated using the SMR, is significantly higher after a long, 20-yearlong period of exposure and its value ranges from 1.47 (95\% CI: $1.30-1.66$ ) to 3.91 (95\% CI: $3.49-4.37$ ) $(30-32,38)$. An increased risk of death (SMR) due to chronic obstructive pulmonary disease in the workers exposed to silica reported by Scarselli et al. (32) and Calvert et al. (39) is as follows: 1.43 (95\% CI: 1.14-1.79) and $\mathrm{OR}=4.38$ (95\% CI: 3.39-5.67). Those values were not confirmed by Marinaccio et al. whose SMR was equal to 0.79 (95\% CI: 0.71-0.87) (31). Similarly, in the case of chronic bronchitis, higher SMR values amounting to 1.52 (95\% CI: 1.19-1.94) were estimated in Scarselli studies (32), which were not confirmed by Marinaccio et al. (SMR $=0.84$ (95\% CI: 0.75-0.94)) (31).

Crystalline silica is not considered a factor that may contribute to the development of asthma (3). Epidemiological studies have failed to demonstrate a relationship between the frequency of fatal cases due to asthma (30-32) or emphysema (30) and exposure to silica.

\section{Lung cancer}

Lung cancer belongs to the most common tumors diagnosed in the general population, and its major risk factor is tobacco smoking. A significant risk is also related to factors of occupational origin. The International Agency for Research on Cancer (IARC) in 1997 decided that there was sufficient evidence in the case of humans for carcinogenicity of inhaled crystalline silica in a form of quartz and cristobalite from occupational sources, and included them into group 1 - carcinogenic to humans (1). In 2009, the Working Group, after reviewing the results of the available studies confirmed this classification, specifying lung as the only target organ (41).

The mechanism of carcinogenicity of crystalline silica is not completely explained. Borm et al. (42) after analyzing more than 200 publications in this field has concluded that the most likely hypothesis for carcinogenicity of crystalline silica is its secondary genotoxic effect resulting from its potent pro-inflammatory activity. Exposure to crystalline silica may result in the development of all major histological types of lung cancer, such as squamous cell carcinoma, adenocarcinoma and small cell carcinoma $(43,44)$.

Quantitative estimation of the risk of lung cancer attributable to occupational exposure to quartz and cristobalite obtained in the meta-analysis of the results of many epidemiological studies is shown in the Table 3. Research conducted in the people occupationally exposed to crystalline silica indicates that the relative risk (RR) ranges from 0.97 (95\% CI: 0.68-1.38) among the non silicotic subjects to 3.27 (95\% CI: 1.32-8.2) among the silicotic only (50) and the SMR from 1.2 (95\% CI: $1.1-1.3$ ) to 2.15 (95\% CI: $1.63-3.66)$ (this data were not adjusted for smoking) $(45,51)$. 


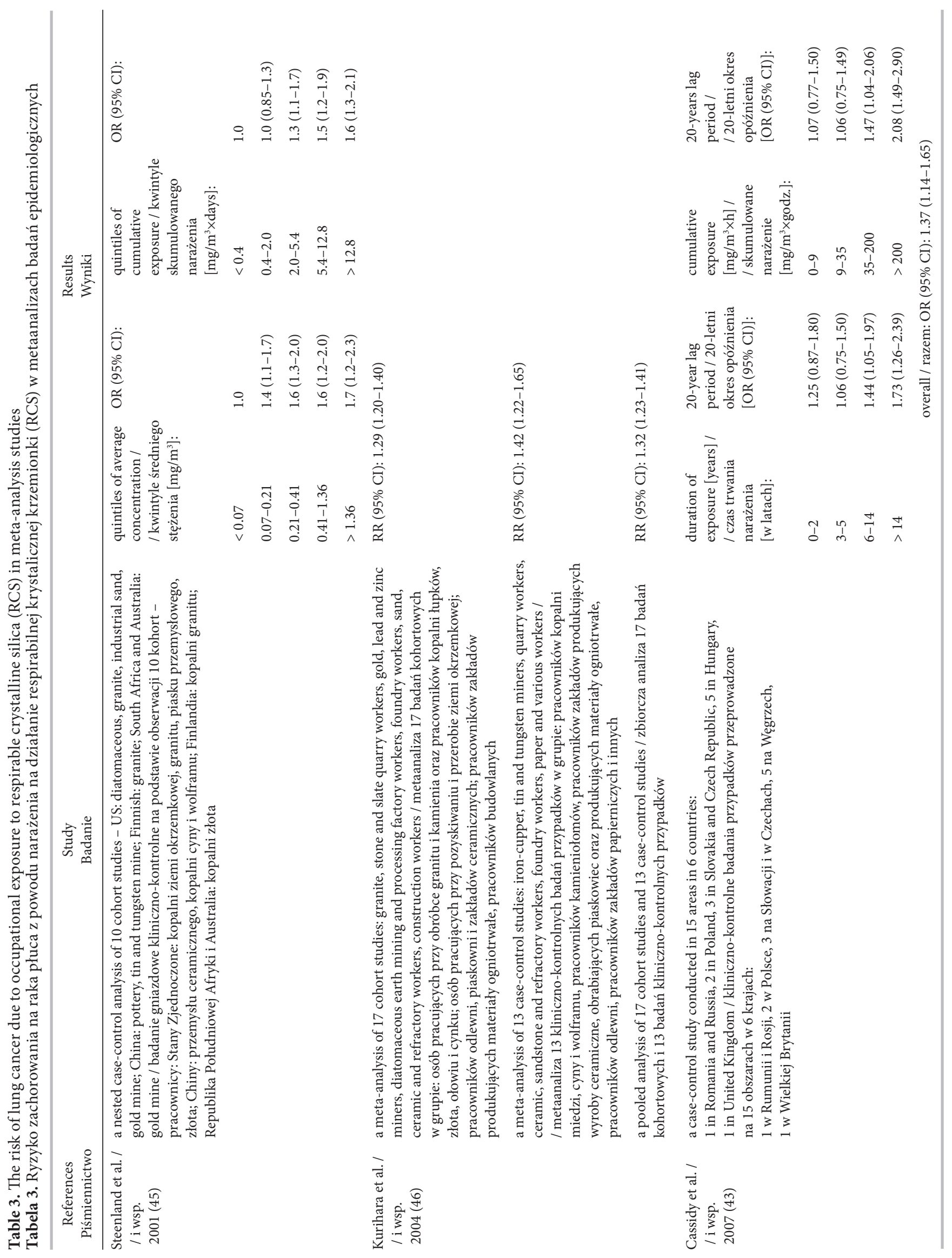




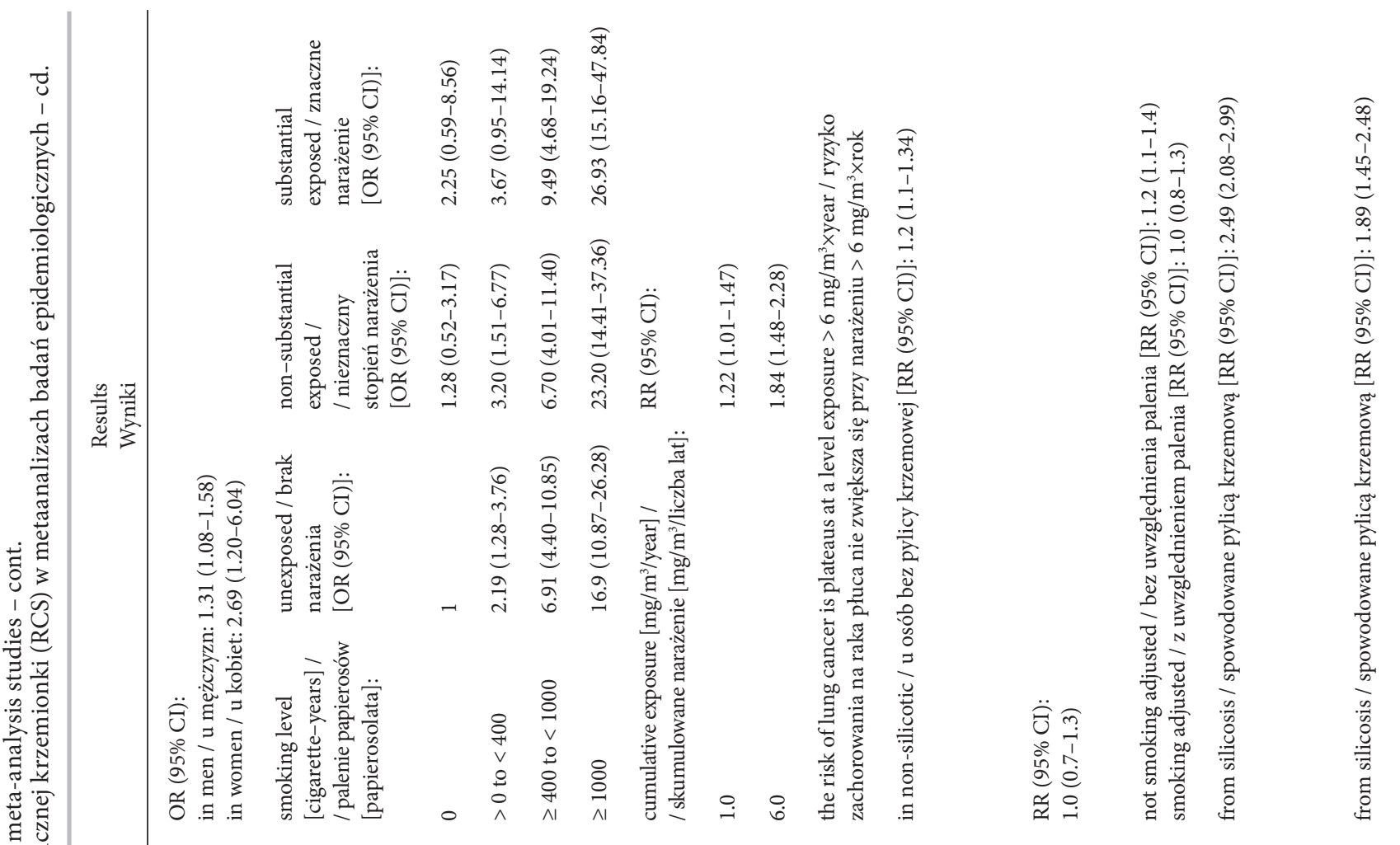

零

政

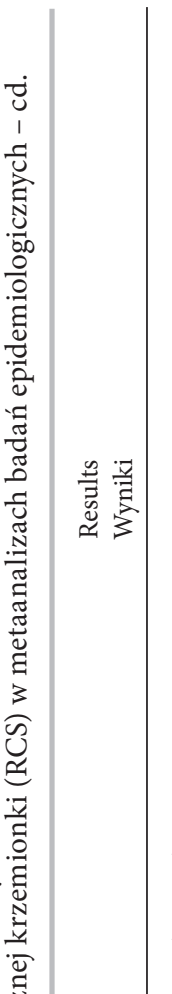

के

$\stackrel{\Xi}{\Xi}$

:

总言

.

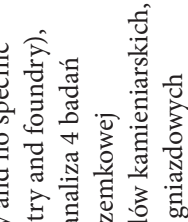

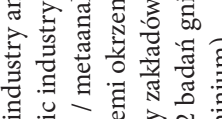

E

त.

कृत

政

苟

䒽录

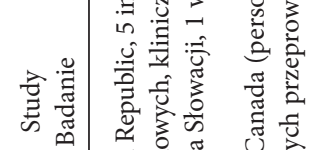

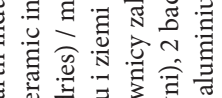

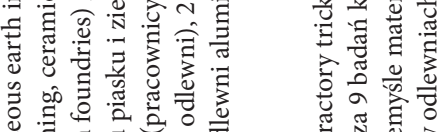

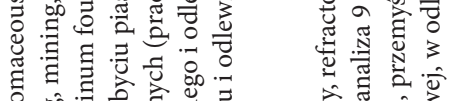

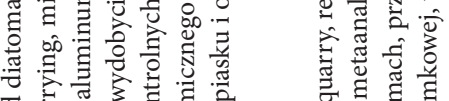

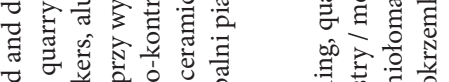

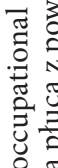

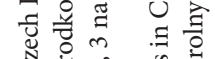

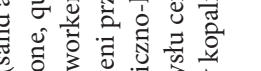

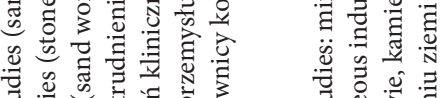

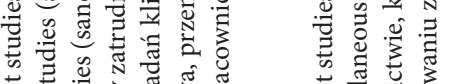

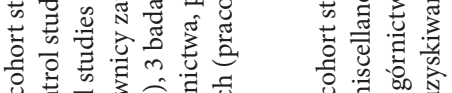

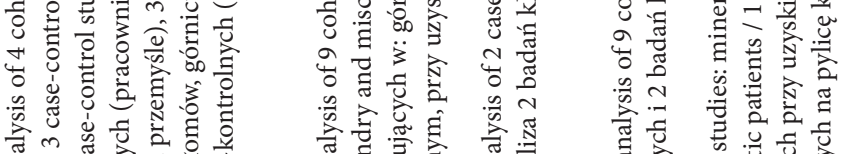

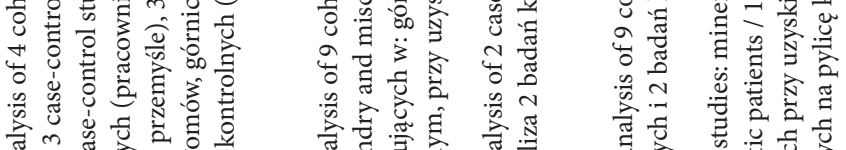

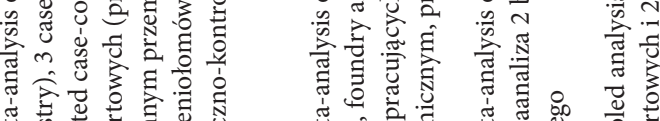

क्ष

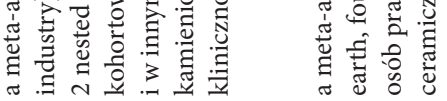

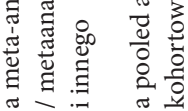

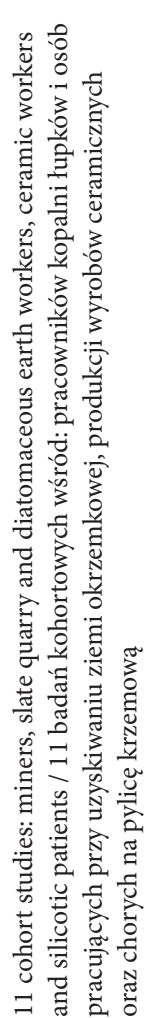

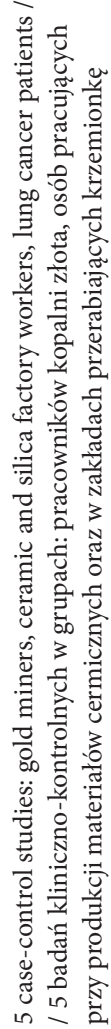

늘

है ते

造

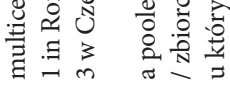

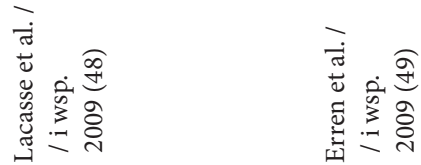

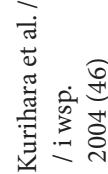




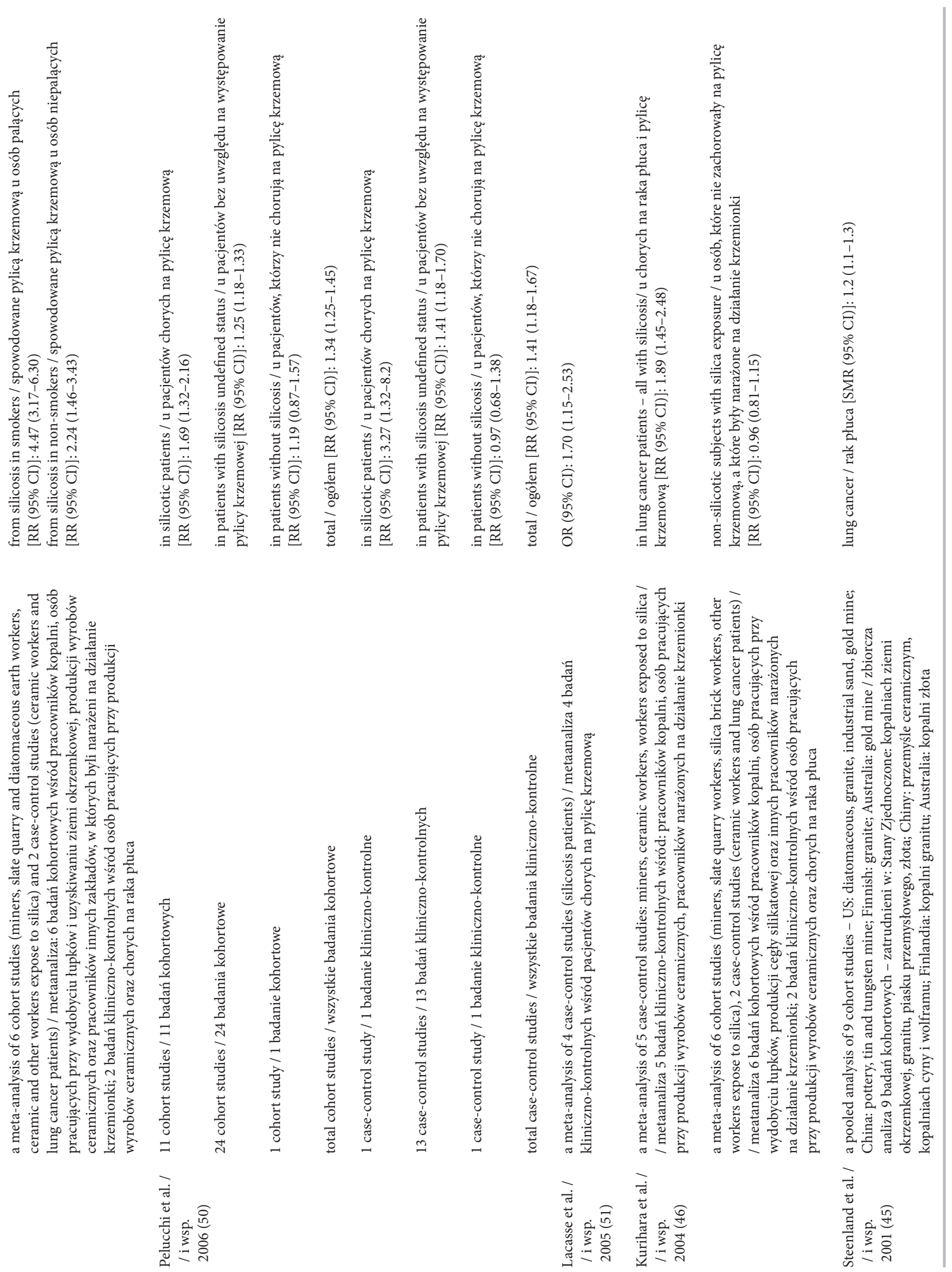


The increased risk of lung cancer due to exposure to quartz and cristobalite depends primarily on:

- Silicosis diagnosis and the time elapsed since the diagnosis $(1,10,33,46,50)$; $\mathrm{RR}$ or odds ratio (OR) of the lung cancer patients with silicosis is the highest, ranging from 1.7 (95\% CI: $1.15-2.53$ ) to 3.3 (95\% CI: 1.32-8.2), while an increased risk was not recorded in the exposed groups without pathological changes in radiological image of the lung, and this increase was not significant and did not exceed the value of 1.19 (95\% CI: 0.87-1.57) (44,46,49-51),

Cumulative exposure to respirable crystalline silica and the maximum intensity of exposure $(1,3,29,33,43,45,48)$; in the case of exposure to small doses - up to about $1-2 \mathrm{mg} / \mathrm{m}^{3} \times$ years - the risk of lung cancer was not increased or the recorded increase was at the border of statistical significance $(29,48)$, while in the case of higher exposure levels the RR or OR adopted values about 2.0 $(29,43-45,48)$. According to Steenland et al. and Lacasse et al., the growing trend of the risk in response to higher cumulative exposure levels continues until about $6 \mathrm{mg} / \mathrm{m}^{3} \times$ years, above which there is no further increase $(45,48)$.

Just like silicosis, gender is another factor that may affect the level of cancer risk. In the studies by Olsson et al., OR of lung cancer in women exposed to silica was 2 -fold higher than in men (47). Lung cancer risk is probably not dependent on the source of exposure or forms of crystalline silica (43). Interaction between the two risk factors for lung cancer i.e., tobacco smoking and exposure to silica has not been explained. The risk estimated among the silica-exposed tobacco smokers is several times higher as compared with the risk in the exposed non-smokers (44). The character of interaction between tobacco smoking and exposure to silica can be described as being somewhere between additive and multiplicative $(43,46)$.

Comparison of the RR or OR values for different lung carcinogens in work environments seems to indicate that crystalline silica appears to be a weaker carcinogen than soluble nickel, arsenic, cadmium and chromiumVI $(33,45,46)$.

\section{Cancers other than lung cancer}

People who are occupationally exposed to crystalline silica, apart from having an elevated frequency of lung cancer were found to be at a higher risk of other cancers, such as stomach, liver, esophageal, pancreatic, intestinal, bone, pharyngeal, skin, brain and kidney 
cancer $(1,3,39)$. However, epidemiological studies have not definitively proven a relationship between exposure to crystalline silica and the occurrence of tumors at locations other than the lung $(3,41)$.

\section{Autoimmune diseases}

Activation of the immune system by crystalline silica deposited in the alveoli is linked with an increased risk of autoimmune diseases in the silica-exposed patients: systemic sclerosis (scleroderma), rheumatoid arthritis or Caplan's syndrome, systemic lupus erythematosus, systemic vasculitis $(3,39,52-55)$. Elevated frequencies were also recorded for sarcoidosis, dermatomyositis, dermatopolymyositis, autoimmune hemolytic anemia $(3,39,52)$.

The pathogenesis of autoimmune diseases in the patients exposed to silica has not been yet completely explained. Based on experimental results, it is believed that crystalline silica may show an adjuvant effect by non-specifically enhancing the immune response to the dust, and triggering or enhancing the development of the quoted diseases $(39,52,54)$.

The frequency of those diseases may be also affected by genetic susceptibility and some environmental factors, such as the relationship between the observed number of cases of rheumatoid arthritis and the geographic latitude of the habitats of the silica-exposed people (53). The development of scleroderma seems to result also from silica directly penetrating the skin of the exposed people (3). The increased incidence of arthritis and systemic rheumatoid sclerosis in the patients diagnosed with silicosis has been confirmed by epidemiological studies $(3,39,52,54)$.

In contrast, the relationship between exposure to crystalline silica and other autoimmune diseases is not obvious, although some studies reported increased OR of the development of these diseases in the exposed people $(39,56)$.

\section{Chronic kidney diseases}

Chronic renal disease observed in an increased number of cases among the workers exposed to crystalline silica is supposed to be associated with 3 possible mechanisms of their development: deposition in the kidneys of immune complexes resulting from the inflammatory processes taking place in the lungs; disorders of the immune system leading to autoimmunization; or direct nephrotoxicity of the silica transported by blood from alveoli to the kidneys $(3,39,57-59)$.

Harmful effects of crystalline silica are associated with a variety of chronic kidney diseases, including glomerulonephrititis and end-stage kidney diseases. The results of epidemiological studies on the relationship between exposure and various pathological changes in the kidneys are not clear $(11,38,39,58,59)$. The risk of chronic kidney disease assessed by Steenland et al. (11) based on pooled analyses of the results of three cohorts was increased in proportion to the exposure to crystalline silica; the OR in the upper quartile of cumulative silica exposure above $1.67 \mathrm{mg} / \mathrm{m}^{3} \times$ years was 3.93 (95\% CI: 1.31-11.76), and the SMR for all the exposed was 1.41 (95\% CI: 1.05-1.85).

In a recent case-control study, the OR of the development of chronic renal disease in the exposed people was equal to 1.40 (95\% CI: 1.04-1.89) and was also dependent on the dust dose; in a group of less exposed people the OR was 1.20 (95\% CI: 0.77-1.86), and in the longer exposure group it was 1.76 (95\% CI: 1.14-2.71). Similar values of the OR were assessed for renal insufficiency, 1.74 (95\% CI: 1.05-2.87) and for end-stage kidney diseases, 1.75 (95\% CI: 0.76-4.01) although the latter value was not statistically significant (59).

\section{Health effects in the context of the current limit values}

For silicosis (a critical effect of exposure to respirable crystalline silica, also essential for the possibility of secondary development of lung cancer), the NOAEL (No Observed Adverse Effect Level) has not been established (60). Occupational exposure limit values for crystalline silica are currently set at levels which do not eliminate, although significantly restrict, the risk of adverse health effects.

In a large number of countries in Europe and worldwide, the hygienic standards for this harmful agent are at the level recommended by the NIOSH (3) and the European Commission SCOEL (Scientific Committee on Occupational Exposure Limits) (60), i.e., $0.05 \mathrm{mg} / \mathrm{m}^{3}$ or 2-fold higher $-0.1 \mathrm{mg} / \mathrm{m}^{3}$.

Epidemiological studies of the exposed people show that exposure to $0.05 \mathrm{mg} / \mathrm{m}^{3}$ (Table 4) is associated with the risk of silicosis ranging from about one to several percent $(16,22,26)$, one percent additional risk of lung cancer (45) and a few percent risk of other respiratory (excluding infectious) diseases (22).

Exposure to quartz and cristobalite at a concentration of $0.1 \mathrm{mg} / \mathrm{m}^{3}$ causes silicosis development in at least 1 (to several dozen) percent of people $(16,22,23,57)$ and other pulmonary diseases (except cancer) in $10 \%$ of the exposed people (22). In this exposed group, the additional risk of death from both pneumoconiosis 
Table 4. The risk of health effects of exposure to respirable crystalline silica (RCS) at concentrations close to the current limit values Tabela 4. Ryzyko wystąpienia skutków zdrowotnych związanych z narażeniem na respirabilną krzemionkę krystaliczną (RCS) występującą w stężeniu zbliżonym do obowiązujących wartości dopuszczalnych

\begin{tabular}{|c|c|c|c|c|c|}
\hline & $\begin{array}{r}\text { Exposure } \\
\text { Narażenie na dz }\end{array}$ & $\begin{array}{l}\text { o RCS } \\
\text { iałanie RCS }\end{array}$ & Ryzyk & Risk of health effects or subgroup & \\
\hline concentration & duration & cumulative exposure & & & References \\
\hline $\begin{array}{l}\text { stężenie } \\
{\left[\mathrm{mg} / \mathrm{m}^{3}\right]}\end{array}$ & $\begin{array}{l}\text { [w latach] } \\
\text { [ zzas narażenia }\end{array}$ & $\begin{array}{l}\text { skumulowane narażenie } \\
{\left[\mathrm{mg} / \mathrm{m}^{3} \times \text { liczba lat }\right]}\end{array}$ & $\begin{array}{l}\text { ILO cat. / kat. } \\
\quad \text { ILO (9) }\end{array}$ & $\%$ & \\
\hline & & & & $\begin{array}{l}\text { risks of silicosis / ryzyko zachorowania } \\
\text { na pylicę krzemową }\end{array}$ & \\
\hline $0.025-0.05$ & 40 & $1.00-2.00$ & $>1 / 0$ & 13.0 & Kreiss et al. / i wsp. 1996 (26) \\
\hline 0.05 & 40 & 2.00 & $>1 / 1$ & 0.4 & Muir et al. / i wsp. 1989 (16) \\
\hline 0.05 & 45 & 2.25 & $>1 / 0$ & 7.5 & Park et al. / i wsp. 2002 (22) \\
\hline $0.05-0.1$ & 40 & $2.00-4.00$ & $>1 / 0$ & 34.0 & Kreiss et al. / i wsp. 1996 (26) \\
\hline $0.05-0.1$ & 40 & $2.00-4.00$ & $>1 / 1$ & $2.0-11.0$ & Chen et al. / i wsp. 2005 (19) \\
\hline 0.10 & 45 & 4.50 & $>1 / 0$ & 14.0 & Park et al. / i wsp. 2002 (22) \\
\hline 0.10 & 40 & 4.00 & $>1 / 1$ & 1.2 & Muir et al. / i wsp. 1989 (16) \\
\hline 0.10 & 45 & 4.50 & $>1 / 1$ & 35.0 & Steenland and / i Brown 1995 (23) \\
\hline 0.10 & 45 & 4.50 & $>1 / 1$ & $47.0-77.0$ & Steenland 2005 (57) \\
\hline & & & & $\begin{array}{l}\text { excess lifetime risk of lung disease other } \\
\text { than cancer and infectious diseases / } \\
\text { / dodatkowe całożyciowe ryzyko } \\
\text { zachorowania na choroby płuc inne niż rak } \\
\text { czy choroby zakaźne }\end{array}$ & \\
\hline 0.05 & 45 & 2.25 & - & 5.4 & Park et al. / i wsp. 2002 (22) \\
\hline 0.10 & 45 & 4.50 & 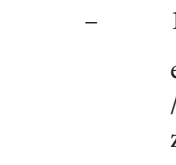 & $\begin{array}{l}10.0 \\
\text { excess lifetime risk of lung cancer / } \\
\text { / dodatkowe całożyciowe ryzyko } \\
\text { zachorowania na raka płuca }\end{array}$ & \\
\hline 0.05 & 40 & 2.00 & - & 1.3 & Steenland et al. / i wsp. 2001 (45) \\
\hline 0.10 & 40 & 4.00 & 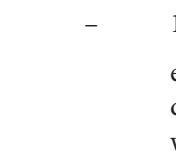 & $\begin{array}{l}1.7 \\
\text { excess lifetime risk of end-stage renal } \\
\text { disease / dodatkowe całożyciowe ryzyko } \\
\text { wystąpienia schyłkowej niewydolności nerek }\end{array}$ & Steenland et al. / i wsp. 2001 (29) \\
\hline 0.10 & 45 & 4.50 & 1 & $\begin{array}{l}5.1 \\
\text { risk of death from silicosis / ryzyko zgonu } \\
\text { z powodu pylicy krzemowej }\end{array}$ & Steenland 2005 (57) \\
\hline $0.025-0.05$ & 45 & $1.12-2.25$ & - & $\begin{array}{l}0.6 \\
\text { (at the age of } 75 \text { years) / (w wieku } 75 \text { lat) }\end{array}$ & Steenland 2005 (57) \\
\hline 0.05 & 45 & 2.25 & - & $\begin{array}{l}0.6 \\
\text { (at the age of } 65 \text { years) / (w wieku } 65 \text { lat) }\end{array}$ & Mannetje et al. / i wsp. 2002 (27) \\
\hline $0.06-0.1$ & 45 & $2.70-4.70$ & - & $\begin{array}{l}1.9 \\
\text { (at the age of } 75 \text { years) / (w wieku } 75 \text { lat) }\end{array}$ & Steenland 2005 (57) \\
\hline 0.10 & 45 & 4.50 & - & $\begin{array}{l}1.3 \\
\text { (at the age of } 65 \text { years) / (w wieku } 65 \text { lat) }\end{array}$ & Mannetje et al. / i wsp. 2002 (27) \\
\hline & & & & $\begin{array}{l}\text { excess risk of death from lung cancer / } \\
\text { / dodatkowe ryzyko zgonu z powodu raka płuca }\end{array}$ & \\
\hline 0.10 & 45 & 4.50 & - & 1.7 & Steenland 2005 (57) \\
\hline & & & & $\begin{array}{l}\text { excess risk of death from renal disease / } \\
\text { / dodatkowe ryzyko zgonu z powodu } \\
\text { niewydolności nerek }\end{array}$ & \\
\hline 0.10 & 45 & 4.50 & - & 1.8 & Steenland 2005 (57) \\
\hline
\end{tabular}


and lung cancer is almost $2 \%(27,57)$. The risk of death from one of the renal diseases, a category heretofore rarely considered as the effect of exposure to crystalline silica, reaches a similar value (57).

All of the above values of the risks associated with exposure to quartz and cristobalite exceed the threshold of acceptable risk, i.e., $0.1 \%$.

\section{CONCLUSIONS}

The review of the results of this research on the health effects of exposure to respirable crystalline silica confirms its multi-faceted harmful effects. In addition to the diseases developing at the places of respirable dust deposition, i.e., silicosis and its complications, lung cancer and other non-neoplastic respiratory diseases, exposure to respirable crystalline silica may be responsible for the development of diseases in other organs, such as kidneys, as well as systemic diseases, such as systemic silicosis, autoimmune diseases (systemic sclerosis, rheumatoid arthritis, systemic lupus erythematosus, systemic vasculitis).

The prevalence of harmful health effects of respirable crystalline silica mainly depends on the concentration of the dust in the air in the workplace and the exposure time. Prolonged, a 40- to 45-year exposure, even at exposure levels close to the current limit values of $0.05-0.1 \mathrm{mg} / \mathrm{m}^{3}$, does not exclude, but significantly reduces, the risk of developing silicosis, lung cancer and other non-malignant respiratory and renal diseases.

Complete elimination of crystalline silica dust from the work environment is not feasible, and the main way to reduce adverse health effects of the exposure is to minimize exposure and the use of personal respiratory protection in situations when concentrations of particulate matter cannot be reduced. Further studies on the influence of the surface characteristics of particles of crystalline silica in their interactions with cells, investigations into mechanisms and carcinogenic potential of silica and its interaction with tobacco smoke, and comorbid dusts in the work environment could contribute to more effective protection of the health of the exposed workers.

\section{REFERENCES}

1. International Agency for Research on Cancer. Monographs on the evaluation of carcinogenic risks to humans. Volume 68: Silica, Some Silicates, Coal Dust and para-Aramid Fibrils. Lyon; 1997 [cited 2013 Jul 15].
Available from: http://monographs.iarc.fr/ENG/Monographs/vol68/mono68-6.pdf.

2. The Mineral and Locality Database. Quartz. [cited 2013 Jul 12]. Available from: www.mindat.org./min-3337.html.

3. National Institute for Occupational Safety and Health. Hazard Review. Health Effects of Occupational Exposure to Respirable Crystalline Silica. Publication No. 2002-129. Cincinnati: U.S. National Institute for Occupational Safety and Health; 2002.

4. Ding M, Chen F, Shi X, Yucesoy B, Mossman B, Vallyathan V. Diseases caused by silica: Mechanisms of injury and disease development: Review. Int Immunopharm. 2002;2:173-82, http://dx.doi.org/10.1016/S15675769(01)00170-9.

5. Greenberg MI, Waksman J, Curtis J. Silicosis: A review. Dis. Mon. 2007;53(8):394-416, http://dx.doi.org/10.1016/ j.disamonth.2007.09.020.

6. Tse LA, Li ZM, Wonk TW, Fu ZM, Yu TS. High prevalence of accelerated silicosis among gold miners in Jiangxi, China. Am J Ind Med. 2007;50:876-80, http://dx.doi.org/10.1002/ajim.20510.

7. Mossman BT, Churg A. Mechanisms in the pathogenesis of asbestos and silicosis. Am J Respir Crit Care Med. 1998;157(5):1666-80, http://dx.doi.org/10.1164/ajrccm.157.5.9707141.

8. Graham WG, Vacek PM, Morgan WK, Muir DC, SiscoCheng B. Radiographic abnormalities in long-tenure Vermont granite workers and the permissible exposure limit for crystalline silica. J Occup Environ Med. 2001;43(4):412-7.

9. International Labour Office. Guidelines for the use of the ILO international classification of radiographs of pneumoconiosis. Occupational Safety and Health Series No. 22 (Rev. 2000). Geneva; 2002 [cited 2012 Dec 10]. Available from: http://www.ilo.org/public/libdoc/ilo/ 2002/102B09_423_engl.pdf.

10. American Conference of Governmental Industrial Hygienists. Silica, Crystalline: $\alpha-Q u a r t z$ and Cristobalite. Documentation of TLVs and BEIs. Cincinnati; 2010, CD-ROM.

11. Steenland K, Attfield M, Mannejte A. Pooled Analyses of renal disease mortality and crystalline silica exposure in three cohorts. Ann Ocuup Hyg. 2002;46(Suppl 1):4-8, http://dx.doi.org/10.1093/annhyg/mef601.

12. Finkelstein MM. Silica, silicosis, and lung cancer: A risk assessment. Am J Ind Med. 2000;38(1):8-18, http://dx. doi.org/10.1002/1097-0274(200007)38:1 < 8::AID-AJIM2 > 3.0.CO;2-\#.

13. Graham WBG, Ashikaga T, Hemenway D, Weaver S, O'Grady RV. Radiographic abnormalities in Vermont 
granite workers exposed to low levels of granite dust. Chest. 1991;100(6):1507-14, http://dx.doi.org/10.1378/ chest.100.6.1507.

14. Love RW, Waclawski ER, Maclaren WM, Wetherill GZ, Groat $\mathrm{SH}$, Porteous RH, et al. Risk of respiratory disease in the heavy clay industry. Occup Environ Med. 1999;56(2):124-33.

15. Miller BG, Hagen S, Love RG, Soutar CA, Cowie HA, Kidd MW, et al. Risk of silicosis in coalworkers exposed to unusual concentrations of respirable quartz. Occup Environ Med. 1998;55(1):52-8.

16. Muir DCF, Julian JA, Shannon HS, Verma DK, Sebestyen A, Bernholz CD. Silica exposure and silicosis among Ontario hardrock miners: III. Analysis and risk estimates. Am J Ind Med. 1989;16(1):29-43, http://dx.doi. org/10.1002/ajim.4700170216.

17. Cherry NM, Burgess GL, McDonald JC. Crystalline silica and risk of lung cancer in the potteries. Occup Environ Med. 1998;55(11):779-85.

18. Hnizdo E, Sluis-Cremer GK. Risk of silicosis in a cohort of white South African gold miners. Am J Ind Med. 1993; 24(4):447-57, http://dx.doi.org/10.1002/ajim.4700240409.

19. Chen W, Hnizdo E, Chen JQ, Attfield MD, Gao P, Hearl F, et al. Risk of silicosis in cohorts of Chinese tin and tungsten miners, and pottery workers (I): An epidemiological study. Am J Ind Med. 2005;48(1):1-9, http://dx.doi.org/10.1002/ajim.20174.

20. Buchanan D, Miller BG, Soutar CA. Quantitative relationships between exposure to respirable quartz and risk of silicosis. Occup Environ Med. 2003;60:159-64, http://dx.doi.org/10.1136/oem.60.3.159.

21. Churchyard GJ, Ehrlich R, teWaterNaude JM, Pemba L, Dekker K, Vermeijs M, et al. Silicosis prevalence and exposure-response relations in South African goldminers. Occup Environ Med. 2004;61(10):811-6, http://dx.doi. org/10.1136/oem.2003.010967.

22. Park R, Rice F, Stayner R, Smith R, Gilbert S, Checkoway $\mathrm{H}$. Exposure to crystalline silica, silicosis and lung disease other than cancer in diatomaceous earth industry workers: A quantitative risk assessment. Occup Environ Med. 2002;59(1):36-43, http://dx.doi.org/10.1136/ oem.59.1.36.

23. Steenland K, Brown D. Silicosis among Gold Miners: Exposure-response analyses and risk assessment. Am J Public Health. 1995;85(10):1372-7.

24. Rosenman KD, Reilly MJ, Rice K, Hertzberg V, Tseng CY, Anderson HA. Silicosis among foundry workers. Am J Epidemiol. 1996;144(9):890-900.

25. Hughes JM, Weill H, Checkoway H, Jones RN, Henry $\mathrm{MM}$, Heyer NJ, et al. Radiographic evidence of silicosis risk in the diatomaceous earth industry. Am J Respir Crit Care Med. 1998;158(3):807-14, http://dx. doi.org/10.1164/ajrccm.158.3.9709103.

26. Kreiss K, Zhen B. Risk of silicosis in a Colorado mining community. Am J Ind Med. 1996;30:529-39.

27. 't Mannetje A, Steenland K, Attfield M, Boffetta P, Checkoway H, DeKlerk N. Exposure-response analysis and risk assessment for silica and silicosis mortality in a pooled analysis of six cohorts. Occup Environ Med. 2002;59(11): 723-8, http://dx.doi.org/10.1136/oem.59.11.723.

28. Hedlund U, Jonnson H, Eriksson K, Jarvholm B. Exposure-response of silicisis mortality in Swedish iron ore miners. Ann Occup Hyg. 2008;52(1):3-7, http://dx.doi. org/10.1093/annhyg/mem057.

29. Steenland K, Sanderson W, Steenland K, Sanderson W. Lung cancer among industrial sand workers exposed to crystalline silica. Am J Epidemiol. 2001;153:695-703.

30. Graham WBG, Costello J, Vacek PM. Vermont granite mortality study: An update with an emphasis on lung cancer. J Occup Environ Med. 2004;46(5):459-66, http://dx.doi.org/10.1097/01.jom.0000126026.22470.6d.

31. Marinaccio A, Scarselli A, Gorini G, Chellini E, Mastrantonio M, Uccelli R, et al. Retrospective mortality cohort study of Italian workers compensated for silicosis. Occup Environ Med. 2006;63(11):762-5, http://dx.doi. org/10.1136/oem.2006.027854.

32. Scarselli A, Binazzi A, Forastiere F, Cavariani F, Marinaccio A. Industry and job-specific mortality after occupational exposure to silica dust. Occup Med. 2011;61(6):422-9, http://dx.doi.org/10.1093/occmed/kqr060.

33. Respirable crystalline silica: Phase 1. Variability in fibrogenic potency and exposure-response relationships for silicosis. Phase 2. Carcinogenicity. HSE Books 2002 [cited 2013 Jul 16]. Available from: http://www.hse.gov.uk/ pubns/priced/eh75-4.pdf (phase 1), http://www.hse.gov. uk/pubns/priced/eh75-5.pdf (phase 2).

34. Stone V, Jones R, Rollo K, Duffin R, Donaldson K, Brown DM. Effect of coal mine dust and clay extracts on the biological activity of the quartz surface. Toxicol Lett. 2004;149(1-3):255-9, http://dx.doi.org/10.1016/ j.toxlet.2003.12.036.

35. Hessel PA, Gamble JF, Nicolich M. Relation between silicosis and smoking. Scand J Work Environ Health. 2003;29(5):329-36, http://dx.doi.org/10.5271/ sjweh.739.

36. Slavin RE, Swedo JL, Brandes D, Gonzales-Vitale JC, Osornio-Vargas A. Extrapulmonary silicosis: A clinical, morphologic and ultrastructural study. Hum Pathol. 1985;16(4):393-412. 
37. Papachristou GI, Papachristou DJ, Schoedel K, McGrath K, Slivka A. Systemic silicosis that involves the pancreas. Gastrointest Endosc. 2006;63(1):170-2.

38. McDonald AD, McDonald JC, Rando RJ, Hughes JM, Weill H. Cohort mortality study of North American industrial sand workers. I. Mortality from lung cancer, silicosis and other causes. Ann Occup Hyg. 2001;45(1):193-9.

39. Calvert GM, Rice FL, Boiano JM, Sheehy JW, Sanderson WT. Occupational silica exposure and risk of various diseases: An analysis using death certificates from 27 states of United States. Occup Environ Med. 2003;60(2):122-9.

40. Park HH, Brendan V, Girdler-Brown BV, Churchyard GJ, White NV, Ehrlich RI. Incidence of tuberculosis and HIV and impairment among former Basotho gold miners. Am J Ind Med. 2009;52(12):901-8, http://dx.doi. org/10.1002/ajim.20767.

41. International Agency for Research on Cancer. Monographs on the evaluation of carcinogenic risks to humans. Volume 100: A review of human carcinogens. Part C: Arsenic, metals, fibres and dusts. Lyon 2010 [cited 2013 Jul 15]. Available from: http://monographs.iarc. fr/ENG/Monographs/vol100C/mono100C.pdf.

42. Borm PJA, Tran L, Donaldson K. The carcinogenie action of crystalline silica: A review of the evidence supporting secondary inflammation-driven genotoxicity as a principal mechanism. Crit Rev Toxicol. 2011;41(9):756-70, http://dx.doi.org/10.3109/10408444.2011.576008.

43. Cassidy A, 't Mannetje A, van Tongeren M, Field JK, Zaridze D, Szeszenia-Dabrowska N, et al. Occupational exposure to crystalline silica and risk of lung cancer: A multicenter case-control study in Europe. Epidemiology. 2007;18(1):36-43, http://dx.doi.org/10.1097/01. ede.0000248515.28903.3c.

44. Vida S, Pintos J, Parent ME, Lavoue J, Siemiatycki J. Occupational exposure to silica and lung cancer: Pooled analysis of two case-control studies in Montreal. Canada Cancer Epidemiol Biomarkers Prev. 2010;19(6):1602-11, http://dx.doi.org/10.1158/1055-9965.EPI-10-0015.

45. Steenland K, Mannetje A, Boffetta P, Stainer L, Attfield M, Chen J. Pooled exposure analyses and risk assessment for lung cancer in 10 cohorts of silica-exposure workers: An IARC multicentre study. Cancer Causes Control. 2001;12(9):773-84.

46. Kurihara N, Wada O. Silicosis and smoking strongly increase lung cancer risk in silica-exposure workers. Ind Health. 2004;42(3):303-14.

47. Olsson AC, Gustavsson P, Zaridze D, Mukeriya A, Szeszenia-Dąbrowska N, et al. Lung cancer risk attri- butable to occupational exposures in a multicenter casecontrol study in central and eastern Europe. J Occup Environ Med. 2011;53(11):1262-7, http://dx.doi.org/10.1097/ JOM.0b013e318234e2d2.

48. Lacasse Y, Martin S, Gagne D, Laghal L. Dose-response meta-analysis of silica and lung cancer. Cancer Causes Control. 2009;20(6):925-33, http://dx.doi.org/10.1007/ s10552-009-9296-0.

49. Erren TC, Glende CB, Morfeld P, Piekarski C. Is exposure to silica associated with lung cancer in the absence of silicosis? A meta-analytical approach to an important public health question. Int Arch Environ Health. 2009;82(8):997-1004, http://dx.doi.org/10.1007/s00420008-0387-0.

50. Pelucchi C, Pira E, Piolatto G, Coggiola M, Carta P, La Vecchia C. Occupational silica exposure and lung cancer risk: A review of epidemiological studies 1996-2005. Ann Oncol. 2006;17(7):1039-105, http://dx.doi.org/ 10.1093/annonc/mdj125.

51. Lacasse Y, Martin S, Simard S, Desmeules M. Metaanalysis of silicosis and lung cancer. Scand J Work Environ Health. 2005;31(6):450-8, http://dx.doi.org/10.5271/ sjweh.949.

52. Parks CG, Conrad K, Cooper GS. Occupational exposure to crystalline silica and autoimmune diseases. Environ Health Perspect. 1999;107(Suppl 5):793-802.

53. Schreiber J, Koschel D, Kekow J, Waldburg N, Goette A, Merget R. Rheumatoid pneumoconiosis (Caplan syndrome). Eur J Intern Med. 2010;21:168-72, http://dx.doi. org/10.1016/j.ejim.2010.02.004.

54. Cooper GS, Miller FW, Germolec DR. Occupational exposures and autoimmune diseases. Int Immunopharmacol. 2002;2(2-3):303-13.

55. Mulloy KB. Silica exposure and systemic vasculitis. Environ Health Perspect. 2003;111(16):1933-8.

56. McCornic ZD, Khuder SS, Aryal BK, Ames AL, Khuder SA. Occupational silica exposure as a risk factor for scleroderma: A meta-analysis. Int Arch Occup Environ Health. 2010;83(7):763-9, http://dx.doi.org/10.1007/ s00420-009-0505-7.

57. Steenland K. One agent, many diseases: Exposure-response data and comparative risks of different outcomes following silica exposure. Am J Ind Med. 2005;48(1): 16-23, http://dx.doi.org/10.1002/ajim.20181.

58. Ghahramani N. Silica nephropathy. Int J Occup Environ Med. 2010;1(3):108-15.

59. Vupputuri S, Parks CG, Nylander-French LA, OwenSmith A, Hogan SL, Sandler DP. Occupational silica exposure and chronic kidney disease. Ren Fail. 2012;34(1): 40-6, http://dx.doi.org/10.3109/0886022X.2011.623496. 
60. European Union, Scientific Committee on Occupational Exposure Limits. Recommendation from the Scientific Committee on Occupational Exposure Limits for silica, crystalline (respirable dust). SCOEL/SUM/94, November 2003 [cited 2013 Jul 15]. Available from: http://ec.europa.eu/social/BlobServlet?docId = 3858\&la ngId $=$ en.

The use of the article "Health effects of occupational exposure to crystalline silica in the light of current research results" is permitted under license conditions of Creative Commons Attribution-NonCommercial 3.0 (also known as CC-BY-NC), available at http://creativecommons.org/licenses/by-nc/3.0/ $\mathrm{pl} /$ or another language version of this license or any later version of this license published by Creative Commons / Zezwala się na korzystanie $\mathrm{z}$ artykułu „Zdrowotne skutki narażenia zawodowego na krystaliczną krzemionkę w świetle wyników aktualnych badań” na warunkach licencji Creative Commons Uznanie autorstwa - Użycie niekomercyjne 3.0 (znanej również jako CC-BY-NC), dostępnej pod adresem http://creativecommons.org/licenses/by-nc/3.0/ pl/ lub innej wersji językowej tej licencji, lub którejkolwiek późniejszej wersji tej licencji, opublikowanej przez organizację Creative Commons. 